Conference proceedings $2^{\text {nd }}$ and $3^{\text {rd }}$ Regional Innovation \& Entrepreneurship Conference

\title{
Serious gaming for systemic entrepreneurialism
}

\section{Nitie P. Mardjan}

Saxion University of Applied Sciences, n.p.mardjan@saxion.nl

Abstract: The term entrepreneurialism doesn't exist. In this paper it is coined to distinguish entrepreneurship from entrepreneurial behaviour by employees. In an serious gaming experiment among Physical Therapy students, we tried to design a learning intervention to advance entrepreneurial behaviour in a non-business setting.

Keywords: Serious gaming, Physiotherapy

\section{Introduction}

An entrepreneur in this definition starts and maintains a business for personal financial gain and risk. The employee exhibiting entrepreneurial behaviour does the same, but not for personal financial gain and risk (it can be argued that a certain kind and amount of gain and risk are involved, albeit these are not primarily financial). Entrepreneurialism is a relevant proficiency for professionals in general and for health care professionals in the current political and social Dutch climate in particular. This is not something that is widely recognized by health care students, nor until recent, by professionals or teaching faculty for that matter. That is why we have developed a powerful learning environment in the form of a serious game which has proven to motivate and entice both students and teaching faculty.

On both a national and a European scale, society is changing. Societal change is of all times, but it is the magnitude of current movements that appears to be rather exceptional. According to Rotmans (2014) we are currently not just living times of transition, but living a transition of times. And these are not just isolated dramatic changes, but interrelated movements: technologically, economically, ecologically and politically. One could even extrapolate this view on a global scale: the distribution of wealth, knowledge, labour and economic prosperity is shifting 
Conference proceedings $2^{\text {nd }}$ and $3^{\text {rd }}$ Regional Innovation \& Entrepreneurship Conference

substantially (SER, 2015). And these interrelated transitions impact social and socio-economic configurations. Changing forces have not yet settled and might even proof to continue to be present, causing permanent instability of these configurations to a certain extent. With a more specific focus on the public domain in The Netherlands, (international) developments have an impact on the public morale and consequently on responsibilities and relationships of institutions and hence individuals. This leads to the forming of a new configuration of actors on more than one level. Governmental institutions, public organizations and commercial enterprises have to find new ways to interact. This trend obviously increases the demands on individual professional behaviour. After all, the diversity of demands that the professional encounters will increase: the individual client's expectations will rise in pace with his felt financial responsibilities for services rendered to him, while at the same time the professional is held accountable through all kinds of newly developed standards, that just as rapidly are outdated again. This hectic environment requires new ways of professional behaviour and interaction to constantly re-balance effectiveness, or the functionality of a system, and efficiency, the financial feasibility of a system. To be able to keep up with the pace of this constantly changing diversity of demands, the professional needs to achieve and maintain a higher level of proficiency in certain existing competencies, while at the same time he will need to acquire new competencies.

\section{Theoretical background}

Entrepreneurialism, organizational and innovation capacities have become increasingly relevant, if not essential competencies in daily practice of health professionals and thus in the education of education health care students in recent years. Students are expected to learn and become proficient by theoretical study, exposure to project assignments, tutoring and lectures. Although these relatively classic educational facilities are obviously effective in certain contexts, we were not pleased with student motivation in regards to the learning of the competencies mentioned here before. Generalized, these competencies do not naturally have the professional focus of students in vocational health care programs. This may be due to their unjust expectations of the demands of current practice. Therefore we have developed an educational course line that functionally and organically connects entrepreneurialism, innovation and organization with specific health care competencies. The core of this educational course line is formed by a serious game that second year students of the four-year physiotherapy and podiatry education 
Conference proceedings $2^{\text {nd }}$ and $3^{\text {rd }}$ Regional Innovation \& Entrepreneurship Conference

programs participate in. The design of this game is based on the principles of GIMMICS at the Groningen University Institute for Drug Studies (Werf et al, 2004). In the first year phase of their education, students are prepared for effective gaming through lectures, assignments and workshops, in the third year they develop an innovation that is partly based on the competencies they developed through gaming. In the fourth year students apply these competencies in both real practice as well as in their thesis work.

The game allows for individual patient oriented problems, as well as for organizational process design and implementation. At Saxion we use the term 'capacity': for the individual client the capacity to maintain one's health, to improve it and to take charge, for the professional to initiate, facilitate and to support health maintenance and improvement. Part of the increased complexity in the organization of health care is the development of increased variety in health and health care needs. This movement requires other ways of organizing and process designing. The professional no longer solely deals with individual clients, he is responsible for the establishment of health care processes and their financing as well. And he can't do that all by himself, re-design of work processes requires cooperation in- and outside of the own organization, and often interdisciplinary.

\section{Serious gaming as an educational provision}

Serious gaming has been popular for a while in different sectors such as the recruitment industry, health care and to a certain extent in education. Often, digital games are meant when serious gaming is referred to. Digital gaming progresses along a somehow pre-programmed pathway. This is a linear progression, the development and outcome of which can be predicted and is limited. However, there are other forms of learning with the support of a game, or rather: within a game setting environment. The learner is emerged in a physical gaming environment and all his actions are executed in the context of a fictitious, but authentic set-up. Progression, nor outcome can be predicted, since interactions are situational and the context is dynamic. 'Things' happen within the fictitious environment in which participants interact. These 'things' are either interventions by the game management, or initiatives of the gamers themselves. In serious simulation gaming, situations can be designed, contexts can be constructed and manipulated by interventions. This allows for powerful learning: action-reaction in authentic context and in competition. Purposeful interventions can influence the course of 
Conference proceedings $2^{\text {nd }}$ and $3^{\text {rd }}$ Regional Innovation \& Entrepreneurship Conference

action without disrupting the flow of the game. That implies normativity: interventions are purposeful and implicate judgement about previous actions.

\subsection{The case within Physical Therapy}

Such a setting we created for $2^{\text {nd }}$ year physical therapy students at Saxion University of Applied Sciences in 2011. We conducted a pilot for a group of 16 students and when this pilot proved to be successful we implemented the game for all approximately 180 students in yearly cohorts. 45 students in periods of 8 weeks, are involved in the game for 1 day per week. Since then we have continuously developed the game, which was designed to focus on competencies of innovation, entrepreneurship and organization.

The game has a duration of 2 months and is performed 4 times per academic year, allowing for approximately 20 students per game period. Groups of five secondyear students are challenged to compete against each other with the assignment to establish a physical therapy practice and become the largest in terms of revenue. It is an interactive physical game in the fictitious town of Polderveen (pop. 40.000) in a real world environment, i.e. there are rooms, real desks, treatment tables, equipment, computers, telephones and people. Polderveen is characterized by its situation in the natural typical Dutch environment (inland sea, polder) and its different neighbourhoods. Local news and actualities are shared through a digital newspaper. In a pre-game period of 2 weeks, 5 new enterprises are being established by as many groups of 5 physical therapy students over a period of 8 weeks. Students participating in the game are expected to produce a corporate mission statement, a business model canvas, which is then used to create a business plan, a website, logo, promotional materials etc. They are expected to relate to relevant enterprises in or outside of town, to referring doctors, to other professionals and to generate patient influx and establish durable relationships.

The game progresses unpredictably, due to ad hoc interactions between gamers and game management, although there is a rough script of interventions: small and larger events that take place in Polderveen or directly aimed and the individual organizations or therapists. The electronic component in the execution of the game consists of databases (i.e. management cases), a gaming website and an electronic patient filing system. The game has a visible and an invisible environment. The visible part consists of the enterprises, the interaction between gamers and third parties and a website. The invisible game management part consists of the game management and the information system. Interventions are conducted by the game management mostly based on situations, decisions and interactions by and between 
Conference proceedings $2^{\text {nd }}$ and $3^{\text {rd }}$ Regional Innovation \& Entrepreneurship Conference

gamers. Interventions consist of a wide variety of management and patient management problems that may or may not be picked up by the gamers as opportunities. Actors visit the clinics in a variety of roles: as patients, as a representative of an insurance company, as the representative of the professional association, as the daughter of a deceased patient etc. For instance: the therapists in a practice are confronted with the request by an 11-year old girl that wants to be treated for low back problems. However, she hasn't informed her parents about this visit. Her story is well composed and convincing. Practices appear to react in different ways, from no treatment without parents' consent, to contacting the parents, to accepting the girls request without further ado. In the latter situation game management may call the practice in the role of one of the girl's parents, demanding to speak with the therapist in question and expressing their anger. The quality of the response is registered and calculated to contribute (or not) to the organization's revenue.

All practices in the fictitious town of Polderveen can monitor their revenues real time and in relation to the competition. Quality judgement is thus translated into revenue and the intention to perform, i.e. increase patient influx, improve customer satisfaction and improve relationships with referring parties etc., becomes the main constituent of competition. Unlike other educational formats, no direct feedback is provided, nor by teaching faculty, nor by game management or others. Just like in the real world, students are dependent for information on the quality of their actions on (the development of) their analytical skills and obviously may take action to find out. For instance, if they decided to take the girl in the previous example into treatment, they may be wondering why this has costed them revenue. They may be able to repair some of that loss, if they on second thought decide that this was a fallacious action and call the parents. In the game, there is no direct contact between game management and gamers, there are only role players. The shareholder is another example of such a role, played by faculty members. The shareholder has a financial interest in a private practice. His aim for the practice is therefore to perform, gain revenue and grow. His role is to stimulate and agitate the therapists in the practice to continuously be sharp on their actions, to improve their cooperation and to innovate. One of the things he initiates is inter-collegial meetings in which professional behaviour is discussed in relation to the organization's economic performance. For instance: he has discovered from management information that the length of treatment series for the different therapists in differ dramatically. His main question to the assembled group forming the organization is 'how do you as individual therapists, in relation to professional standards, customer satisfaction and economic performance, motivate your professional behaviour?' 
Conference proceedings $2^{\text {nd }}$ and $3^{\text {rd }}$ Regional Innovation \& Entrepreneurship Conference And the second issue addressed is 'how can we discuss these differences so that we can all agree to balancing professional quality with economic performance?'.

\section{Conclusion}

The Dutch Organization for Applied Scientific Research TNO, regarded the effectiveness of serious gaming in education. Educational gaming is a stimulating active and self-directed way of learning. It results in a better understanding of and insight into the subject matter. The simulation of authentic clinical situations makes abstract issues and topics applicable in a practical way. The element of competition motivates students and stimulates students' development, because gaming is consistent with their experiences. These factors and the sense of responsibility for all interactions that students experience, make serious simulation gaming a powerful learning environment (Diggele \& Straetmans, 2001). Existing assessment and research methods are not appropriate for the measurement of the effects of serious gaming. Judgment of students' performance is integrated in the game's progression. Naturally the registration of 'behind the scenes' performance judgements are transparently provided post-game. Internal research shows significant increase in student motivation for the competencies entrepreneurship and organization since the introduction of the educational game (Verschueren, 2011). Aspects of the powerful learning environment that scored significantly higher were professional authenticity, activation, navigation, involvement, adjustment to learning styles, variation and purpose.

\section{References}

Angelides, M., \& Paul, R. (1999). A methodology for specific, total enterprise, roleplaying, intelligent gaming-simulation, environment development. Decision Support Systems, 89-108 (25)

Diggele, J. v., \& Straetmans, G. (2001). Anders opleiden, anders toetsen. In Cito, Perspectief op assessment. Arnhem: Cito

Korthagen, F. \& Lagerwerf, B. (2008). Leren van binnenuit: Onderwijsontwikkeling in een nieuwe tijd. Soest: Nelissen.

Kuiper, C. \& Balm, M. (eds.) (2004). Paramedisch handelen. Het ontwikkelen van beroepsattitudes. Utrecht: Lemna 
Conference proceedings $2^{\text {nd }}$ and $3^{\text {rd }}$ Regional Innovation \& Entrepreneurship Conference

Lewis, M., \& Maylor, H. (2007). Game playing and operations management education. International Journal of Production Economics , 134-149 (105)

Okuda, J., Bryson, E., DeMaria, S., Jacobson, L., Quinones, J., Shen, B. et al. (2009). The Utility of Simulation in Medical Education: What Is the Evidence? Mount Sinai Journal of Medicine. 76, 330-343

Oprins, E, Bakhuys Roozeboom, M., Visschedijk, G. Effectiviteit van serious gaming in het onderwijs. Onderwijsinnovatie. 06 2013, 32-34

Oprins, E., Bakhuys Roozeboom, M., Visschedijk, G., Kistemaker, L. (2013). Effectiviteit van serious gaming in het onderwijs. TNO rapport (R10415). TNO: Soesterberg.

Pittaway L. \& Cope J. (2007). Simulating entrepreneurial learning: integrating experiential and collaborative approaches to learning. Management Learning. 38(2) 211-233 doi: 10.1177/1350507607075776

Schaveling J., Bryan B. \& Goodman M. (2012). Systeemdenken. Van goed bedoeld naar goed gedaan. The Hague: SDU Uitgevers

Simons, R., Bolhuis, A., \& Onstenk, J. (2000). Leertheoretische visie. In J. Onstenk. Op zoek naar krachtige beroepsgerichte leeromgeving (pp. 38-40). 's Hertogenbosch: CINOP

Smith, S. \& Roehrs, C. (2009). High-fidelity simulation: factors correlated with nursing student satisfaction and self-confidence. Nursing Education Perspectives 2: 74-78

Stanley, D. \& Latimer, K. (2010). 'The Ward': A simulation game for nursing students. Nurse Education in Practise 3-6

Verschueren, F. (2011). In search of powerful Learning Environments. A research on Gaming in physical therapy education. Master's thesis. Enschede: Saxion AGZ; 2011.

Vries, C. de, Hagenaars, L., Kiers, H. \& Schmitt, M. (2014). Beroepsprofiel fysiotherapeut. Amersfoort: KNGF

Werf, J. van der, Dekens-Konter, J., Brouwers, J. (2004). A new model for teaching pharmaceutical care services management. Pharmacy Education 4-3 p.165-169 